\title{
Dedication Photograph
}

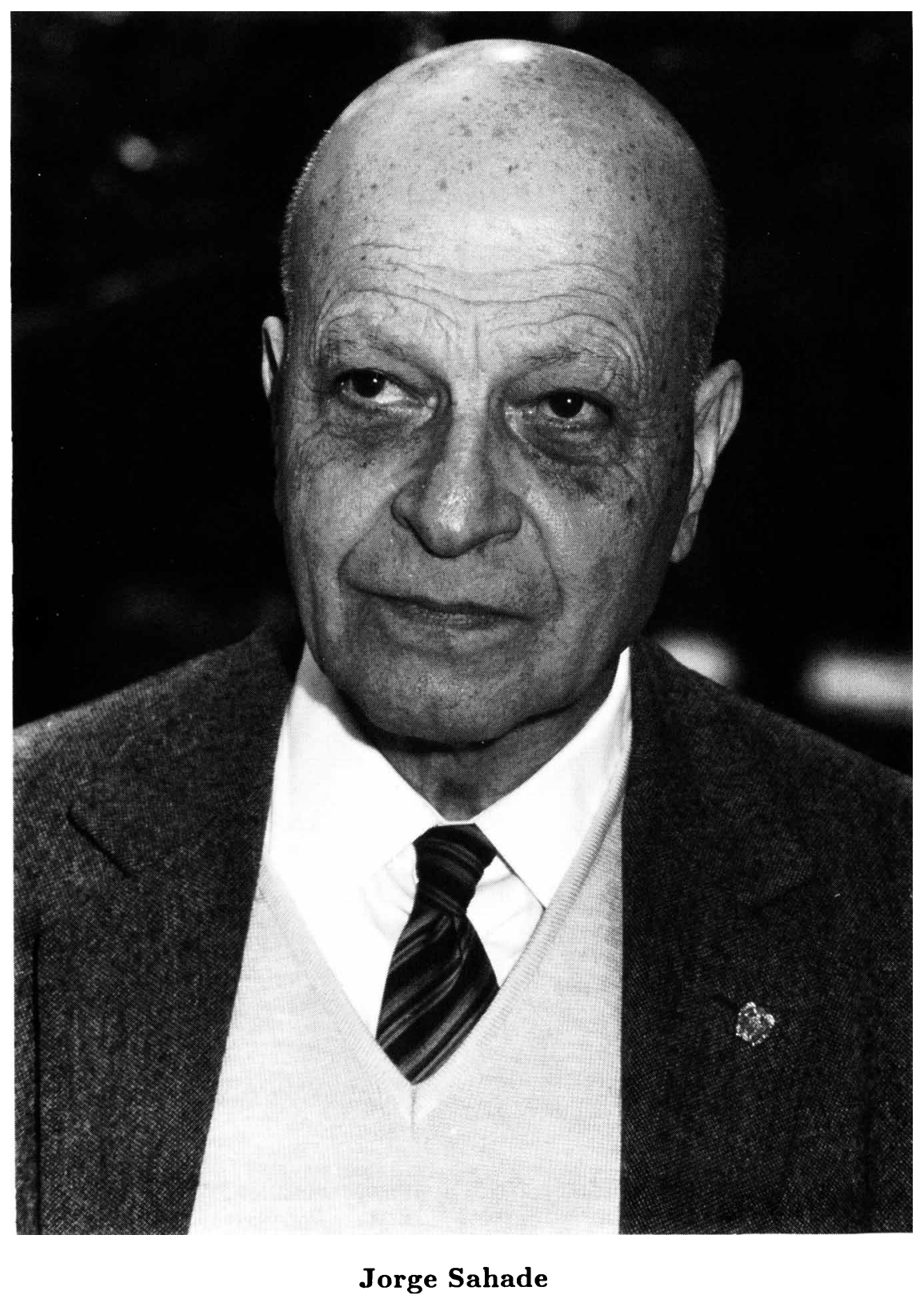

